\title{
Forced Displacement in Turkey: Pushing the Limits of the ECHR System Darren Dinsmore
}

\section{This article has been accepted for publication in International Migration}

This paper presents research findings on regional human rights tribunals and forced displacement. It assesses the response of the European Convention on Human Rights (ECHR) system to 'village destructions' and 'village returns' complaints lodged against Turkey and originating from the conflict between State security forces and the PKK (Partiya Karkarên Kurdistan). Within academic literature the role of the ECHR in Turkey tends to be reduced to discussion of a handful of substantive decisions. This article argues that there is much to be gained from closer examination of the (changing) dynamics of the ECHR in Turkey and the regulation of displacement. Two innovations can be observed from this case-study: a special level of 'protective' access and a proactive approach to fact-finding. The Turkish cases indicate a need for further investigation of the role of fact-finding in cases of displacement and the development of context-specific rules on sustainable returns processes.

Keywords: IDP, Turkey, Kurds, ECHR, fact-finding, remedies

\section{INTRODUCTION}

This paper examines the extensive litigation of forced displacement in Turkey under the ECHR, based on a database of the published decisions of the (former) European Commission of Human Rights ${ }^{i}$ and the European Court of Human Rights. The Turkish cases appeared prior to the adoption of international norms and were a landmark as the first claims of a practice of forced displacement before a regional human rights tribunal. The repetition of complaints and long-running oversight also speak to the unusual role of the ECHR in Turkey. A total of 1,250 individual applications relating to 3,107 applicants were submitted between 1993 and 2010. By examining the resulting 171 cases, decided throughout a 17 year period (1995-2011), ii this paper aims to improve our understanding of how regional human rights mechanisms can be used to challenge displacement and increase the prospects for durable returns. It identifies innovations in ECHR procedure and the creation of core legal rules on forced displacement. Applicants benefitted from a protective form of access and the Commission was surprisingly proactive in conducting fact-finding. The Turkish cases emphasise the limitations of normative analyses in capturing what regional tribunals can offer to victims, NGOs and civil society. The Court's analysis of the legal 
consequences of destruction of property and denial of access or return, on the other hand, discloses an increasing pragmatism at Strasbourg and a failure to push for remedies capable of facilitating sustainable returns.

The entry into force in 2012 of the African Union's Kampala Convention, the first binding treaty on internal displacement, highlights the crucial role of regional human rights actors in the regulation of displacement. In recognising the need for a "completely distinct and binding legal framework" (Giustiniani 2011: 352) the African Union has resolved a long-standing institutional and normative gap. The problem within international law stems from the primacy of refugee protection, under the 1951 Refugee Convention, and its limitation to persons having crossed a national border. The border-crossing distinction became the subject of intense scrutiny during the 1990s given the rapidly increasing scale of internal displacement (Cohen and Deng 1998) and the consequent lack of protection for internally displaced persons (IDPs) (Lee 2001: 456). The lack of a "comprehensive, all-inclusive strategy" (Stavropoulou 1994: 716) or "coherent institutional approach" (Cohen 2004: 461) at the UN further compounded the problem. The creation of a UN Special Representative on Internal Displacement in 1992 (UN Commission on Human Rights 1992) created a distinct space for the development of a legal framework. States' resistance prompted the decision to fuse existing rules within human rights law, humanitarian law and refugee law, rather than add to States' international obligations (Cohen 1998: 4), and a set of non-binding rules was seen to be preferable to a new treaty (Kälin 2008). States cannot be compelled to accept and comply with the various obligations within the UN Guiding Principles on Internal Displacement (UN Commission on Human Rights 1998) and IDPs are neither attributed legal status nor conferred directly enforceable rights. This paper employs the Turkish case-study to investigate the possibilities offered by regional human rights tribunals in cases of forced displacement. The investigation will begin with a brief comment on litigating conflict under the ECHR, then examine access, fact-finding, and state responsibility.

\section{CONFLICT-LAWYERING AND THE ECHR IN TURKEY}

The Northern Irish conflict provides an important context to the Turkish case-study as the leading previous experience of individual petitions under the ECHR regarding 
conflict and emergency measures. The Northern Irish example speaks clearly to the difficulties involved in conflict-lawyering at Strasbourg. In the first instance, McEvoy has identified how the local legal culture "shaped the prevailing ethos of quietism" among lawyers at the initial stages of the conflict, and a subsequent failure to pursue "an overarching legal strategy which might deliver material benefits" (McEvoy 2011: 352, 358). Lack of legal knowledge and diligence in submitting claims also kept various controversial practices away from the Court. Cases alleging discrimination in education, employment and housing, for instance, failed at an early stage due to poor legal representation (Dickson 2010: 46-47). When well-presented claims were submitted, the ECHR system proved largely ineffective as a tool to challenge security policies. The Court's approach to internment, for example, has been criticised for causing "[i]nestimable damage...to the credibility of the Convention" (Dickson 2010: 363).

The same lack of awareness prevailed among lawyers in Turkey despite the State's recognition of the right to individual petition before the Commission in 1987. A seminar given by Kevin Boyle in South-east Turkey in 1992 proved a turning-point as lawyers from the Human Rights Association of Turkey (İnsan Hakları Derneği, IHD) began to work with a team of Kurdish Human Rights Project (KHRP) lawyers to bring cases to Strasbourg. The IHD/KHRP litigation programme led to a remarkable number of judgments finding violations relating to the conflict; 175 decisions as of September 2008 (Committee of Ministers 2008b). The IHD/KHRP network was also crucial to devising and executing a legal strategy that pushed the limits of the ECHR system. The following section will identify an early, qualified success in convincing the ECHR bodies of the existence of special conditions in South-east Turkey.

\section{ADMISSIBILITY: “A BRIDGE OF PETITIONS”}

The 'village destructions' applications were intentionally framed to present the individual claims as the result of State policy, according to which a denial of local redress bore witness to a practice of violations. Applicants typically alleged that members of the security forces or village guards $s^{\mathrm{iii}}$ came to their villages and hamlets 
and destroyed homes and possessions, forcing them to abandon their homes and communities. A prolonged period of State of Emergency Rule (OHAL, Olağanüstü $\mathrm{Hal}$ ) within the region (1987-2002) provided for a broad range of restrictions on rights and a legal basis for forced movement. The majority of applications related to incidents occurring during a two-year period (1993-1994) within the provinces of Diyarbakır and Tunceli; specific temporal and geographic patterns can be observed within each province. At the heart of the complaints was the suggestion that the OHAL system created impunity for a practice of forced displacement. The IHD/KHRP litigation strategy saw cases submitted to Strasbourg prior to the conclusion of domestic investigations. In some cases applications were submitted in the absence of domestic complaints, with the potential to create "a bridge of petitions"iv from South-east Turkey to Strasbourg. The IHD/KHRP in this way knowingly challenged the subsidiary nature of international human rights law.

Applicants are as a matter of principle of international law required to first seek redress at the national level so as to prevent "domestic courts being superseded by the international organs" (Cançado Trindade 1983: 3). Prior to the Turkish cases the ECHR bodies had, however, recognised an exception to the exhaustion of domestic remedies rule in the context of alleged 'administrative practices' of human rights, situations involving a "repetition of acts" and "official tolerance" of such acts (Denmark et al v. Greece 1969: p 195). The Commission first recognised the ability of individuals to submit such claims in its examination of the treatment of detainees in Northern Ireland, in a case in which Kevin Boyle was one of the applicants' lawyers (Donnelly 1973). It also accepted that domestic remedies would "tend to be rendered ineffective" or "half-hearted and incomplete" in the case of an administrative practice of torture or ill-treatment ('the law', para 3). A subsequent decision rejecting the claims, on the basis that applicants had either received compensation or that civil proceedings were ongoing, appeared to reign in the potential for individual claimants (Donnelly 1975). The IHD/KHRP strategy regarding Turkey was intent on succeeding where Donnelly had failed. In each case the scale of destruction and displacement was claimed to reflect a "high-level Government policy - an administrative practice - in regard to which all remedies are theoretical and irrelevant" (e.g. Akdivar 1994). 
From the very first village destructions cases the ECHR bodies expressed serious concerns with the standard of domestic investigations. In Akdivar (1996) domestic remedies were ruled ineffective owing to a lack of meaningful investigations, the "negligible" prospect of a successful civil claim, and the inability to exclude the applicants' fear of reprisals following domestic complaints. Administrative claims were found to have reasonable prospects of success only where damage was claimed to have been caused by the PKK or during clashes between security forces and the PKK, not regarding allegedly intentional acts of the security forces (Menteş 1997). The Court also ruled that a failure to investigate complaints had created a reasonable belief that it was "pointless" for the applicants to seek domestic remedies (Selçuk and Asker 1998: para 70). In one case a "seriously prejudiced" investigation was closed without the taking of statements from members of the security forces (Ayder 2004: para 60), in another the case file was transmitted for investigation by the very gendarmes alleged to have destroyed the applicant's home (Altun 2004). In case after case the ECHR bodies declared "the existence of special circumstances" which displaced the obligation to exhaust domestic remedies, even where no domestic complaints were lodged (Menteş 1997: paras 59-60).

The ECHR bodies drew a paper-thin line between the individual cases before them and the general situation in Turkey. The protective form of access granted to applicants created a unique oversight of the situation in South-east Turkey. The problem for the Strasbourg bodies was that they were assuming the role of first instance tribunal regarding an issue presenting itself through a large, and growing, body of similar complaints. The same pressure does not arise under the African and Inter-American systems due to the provision for general or actio popularis claims, and collective review, in individual cases. Driven by a concern to prevent a flood of petitions from Turkey, the Commission and Court limited their decisions in two ways. Firstly, they repeatedly stated that the decisions were "confined to the particular circumstances" of each individual case rather than a "general statement that remedies are ineffective in this region of Turkey". Secondly, they ruled in each instance that it was not necessary to examine the alleged administrative practice regarding effective remedies (Article 13 ECHR). 
The unhappy compromise on domestic remedies is but one illustration of the limited capacity of the ECHR complaints procedure regarding alleged systematic violations. The failure to recognise an administrative practice was criticised by Zwaak as a missed opportunity to "send a clear message to the Turkish government" and encourage other States to submit an inter-State claim (Zwaak 1997: 109). The KHRP team also questioned the validity of the ECHR bodies' approach given their repeated decisions finding domestic remedies ineffective (Reidy et al 1997: 165-166). The consistent failure of the Turkish authorities to evidence genuine, effective investigations gave the ECHR bodies little choice but to exercise discretion in applying the exhaustion rule. Its rigid enforcement would have been perverse in light of the realities of access to justice under the OHAL system. By exposing a consistent lack of local redress the IHD/KHRP secured an exceptional role for the Commission, in particular, as 'a de facto court of first instance' (Leach et al 2009: 27). This not only had significant consequences for the ECHR proceedings in each relevant case, but also contributed to a long-lasting expectation of the ECHR system in South-east Turkey. There remains considerably greater awareness of the ECHR than of domestic remedies among IDPs in Turkey as a combined result of the unusual access granted to applicants and a pervasive mistrust of the State (Çelik 2012: 9-10). The following section will examine the ECHR fact-finding process and propose that fact-finding should be viewed as a core aim of human rights litigation regarding displacement, with distinct impacts for victims, NGOS and civil society.

\section{FIRST INSTANCE FACT-FINDING}

The normal application of the exhaustion of domestic remedies rule tends to ensure that facts are established by domestic courts before cases appear at Strasbourg. The immediate effect of recognising the "special circumstances" with respect to remedies in the OHAL region was to recast the role of the ECHR in Turkey. The Commission had previously conducted fact-finding regarding various crises, including the situation in Greece after the 1967 coup d'état (Denmark et al v Greece 1969) and during the Northern Irish conflict (Donnelly; Ireland v. United Kingdom 1976). The decision to conduct fact-finding in the Turkish cases was therefore not 
without precedent. What was unusual regarding Turkey, however, was the Commission's role as first instance fact-finder throughout a series of individual cases. The Turkish conflict cases are conspicuous among the record of ECHR factfinding, comprising 60 of the 92 cases involving fact-finding as of 2009 (Leach et al 2009: 24); including 16 village destructions cases. This proactive approach was the key innovation in the village destructions cases. It also drew the Commission and Court into the most difficult stage of their review of the complaints.

Human rights fact-finding has a recognised capacity to deliver outcomes that speak beyond individual events or cases, particularly regarding situations of conflict and emergency rule. Fact-finding can help to depoliticise proceedings (Helfer and Slaughter 1997-1998: 303) and signal a "commitment to closing gaps in domestic accountability" (Helfer 2008: 144). It can expose "illegitimate actions" or institutional failures and provide "an authoritative factual record", which can then serve as an advocacy tool (Cavallaro and Brewer 2008: 794). Furthermore, the KHRP legal team welcomed the ability of applicants to be heard in-person through the ECHR process (Reidy et al 1997: 171), itself a remedial act. However, the lack of power to compel the attendance of witnesses and submission of documents under the ECHR limited the potential narrative value of fact-finding. The political context to the cases inevitably created additional problems. Vivanco and Bhansali emphasise in this regard the need to "minimize discretion" in order to guarantee the credibility of the process and resulting facts (1998: 424-425). In practice flexibility is an intrinsic feature of human rights fact-finding, and the ECHR rules on admissibility of evidence, the burden of proof, corroboration, and use of inferences have developed on a case-by-case basis. The Turkish cases demonstrate that in the primary aim of establishing facts the need to be "thorough, politically objective, and procedurally fair" (Steiner and Alston 2000: 603) can lead to a balancing act between equality of arms and the desire to secure State participation.

The Turkish government employed various techniques of denial in its response to the allegations, rejected the allegations in successive cases as an abuse of the ECHR system, and attacked the credibility of applicants (Çali 2010). Applications were initially rejected as being merely part of a propaganda campaign, "fabricated, 
produced by influence of the PKK and obtained by deception of the applicants" (Selçuk and Asker 1996: para 140). Applicants' versions of events were dismissed as "completely baseless" (Hasan Ilhan 2004: para 21) and "imaginary" (Ípek 2002). Where the government was prepared to accept that searches or "protective security operations" had been conducted in the applicants' villages or surrounding areas, the destruction of any houses or property was frequently denied (e.g. Hasan Ilhan 2004; Dulaş 1996). In two cases in which the government recognised that applicants' homes and possessions had in fact been destroyed, this was explained as the result of clashes with PKK forces rather than a deliberate act by security forces (Ayder 1999, Ahmet Özkan 2004). The fact-finding process was therefore critical to the proceedings as a whole in uncovering the truth of events in the OHAL region. It also presented a test to the legitimacy of the ECHR. For the IHD/KHRP team fact-finding presented an opportunity to establish a counter-narrative. Moreover, fact-finding was decisive to applicants' prospects of success: only one case examined without fact-finding led to a finding of substantive rather than procedural or remedial violations: the village returns case of Doğan (2004).

Fact-finding inevitably brought to the fore the tension between the scope of the allegations and the right to individual petition. The ECHR system simply did not have the capacity to examine the full picture presented through the applications. Factfinding was conducted in 16 cases, in 12 cases by the Commission, relating to incidents in five provinces; the majority of fact-finding investigations related to Diyarbakır province (11 cases). There was also a clear temporal focus: the factfinding investigations related to incidents occurring in 1992 (2 cases), 1993 (11 cases) and 1994 (3 cases). As further example of the purely representative nature of fact-finding, one application was selected for fact-finding out of a group of 202 applications relating to the alleged destruction of large parts of the town of Lice in Diyarbakir in October 1993 (Ayder 1999). The remaining 201 applications were settled through ex gratia payments totalling just over EUR 4.4m, albeit the Court's decisions recognised the collective nature of the cases by referring to "247 Inhabitants of Lice v Turkey" (e.g. Elek 2001). 
The evidential approach of the Commission and Court was largely driven by problems with the documentary evidence. There was a noted failure on the part of the Turkish authorities to submit documents within time, or at all, and often without sufficient explanation. The Commission was frequently unable to secure access to all operation and incident reports (e.g. Bilgin 2000: para 26), including operational orders for helicopter forces (Ayder 2004: para 36). Records of operations, when received, were "not to be taken at face value" (Orhan 2002: para 269). In Ahmet Özkan (2004) the Government did supply a cache of more than 100 documents, thereby enabling a detailed analysis of the number and status of security forces involved and the ammunition used. The Commission also noted with concern that statements recorded by the IHD and public prosecutors "often appear to recite stereotyped and preconceived assumptions to suit the purpose of the document in question" (Menteş 1996: para 145). Oral testimony was as a result central to the ECHR investigations. A total of 201 individual testimonies were heard over 45 days of hearings. The distribution of witnesses speaks to more intensive efforts in certain cases: almost half of all the witnesses were heard in three cases, 48 in Ahmet Özkan (2004), 30 in Yöyler (2003) and 20 in Ayder (1999). Although evidence was received from a wide range of witnesses on behalf of the parties, significant weight was attached to the opportunity for in-person assessments of applicants: in two cases the Commission decided it could not establish facts on account of the nonattendance of applicants (Gündem 1996, Yılmaz 1997).

The Commission and Court gave initial priority to assessing the reliability and demeanour of applicants and to the existence of corroborative evidence. The government thus bore the responsibility of rebutting claims where applicants and eye-witnesses were judged to have given credible accounts. The ECHR bodies also took a pragmatic view of a lack of clarity regarding dates in the evidence given by or on behalf of applicants, accepting that problems arose due to age, the passage of time and the difficulty of presenting accounts of traumatic events (Selçuk and Asker 1996: para 153). Their assessment of such oral evidence was cautious nonetheless, involving a clear effort to determine the existence and impact of hearsay (e.g. Orhan 2002: para 282), conspiracy or animosity against State officials or public authorities (e.g. Akdivar 1995: paras 205 \& 210), exaggeration (e.g. Ahmet Özkan 2004, para 97), 
and possible PKK responsibility (e.g. Ipek 2004: paras 134,145). The evaluation of the applicant testimony as largely credible and consistent was in direct contrast to that of government witnesses. Oral evidence given by villagers on behalf of the government was frequently judged to lack supporting evidence or to reflect animosity vis-à-vis the inhabitants of the applicants' villages (Menteş 1996: para 163). The evidence of Gendarmerie Commanders was deemed even less convincing. While the Court accepted that officials had been "professional, convincing and reliable" on general matters, the same was not true of their accounts of specific details under questioning (Ahmet Özkan 2004: para 98).

In total, the ECHR bodies established a factual basis for finding state responsibility for acts of destruction and displacement in 12 cases; responsibility was also found for enforced disappearances (Ípek 2004 and Orhan 2002) and the deaths, blindfolding and forced marching of villagers (Ahmet Özkan 2004). Adverse inferences were lied on in only three cases; on the basis of contradictions within official testimony (Hasan Ilhan 2004) and non-attendance of a military general (Ipek 2004, Orhan 2002). The fact-finding reports documented in detail the severity of treatment of applicants and provided an "administrative truth" through the exposure of "a collective attitude on the part of state officials" (Çali 2010: 324). They also generated the first independent narrative of events regarding an area that had long experienced severe restrictions on freedom of expression (Yildiz and Brigham 2006). One former Turkish Representative to Strasbourg complained that the burden of proof had been reversed and the ECHR bodies had "formed an a priori opinion of Turkish culpability" (Gündüz 2001: 19). Such is the legitimacy test posed by human rights fact-finding in politically-charged cases. In reality only one outcome was possible in light of two factors: (1) the repeated government failure to provide information and witnesses, and; (2) the refusal of officials to contemplate security force responsibility in the face of corroborated testimony.

Although the fact-finding process was crucial when understood in terms of exposure, the case-by-case examination limited the scope of the factual findings and the broader narrative generated by the ECHR process. The Court commented in Ipek, for instance, that military operations appeared to have been conducted "within the 
framework of a larger operation being conducted over the surrounding area" (2004: para 137). In another case it noted that "a disturbing amount of relevant questions remained unanswered" (Ayder 2004: para 41). The ECHR lacks the capacity of the Inter-American Court, for instance, to generate a broader narrative of displacement through fact-finding (e.g. Case of the Mapiripán Massacre v. Colombia 2005). Getting to the general truth was beyond the scope of ECHR fact-finding. This should not detract from the exceptional contribution of the ECHR process. The ECHR factfinding process gathered a staggering amount of evidence, evidence that, at the least, consistently exposed an official refusal to recognise security force failings in the "fight against terrorism". The fact-finding hearings gave space for the voices of the displaced and ensured the right to individual petition had purchase in spite of the difficulties of securing documentary evidence. The resulting judgments, entirely dependent on the fact-finding process, were an important advocacy tool. They also impacted on broader political processes: the EU Commission reports on Turkey's accession process rely heavily on the ECHR decisions in evaluating the state of human rights in Turkey. Following the abolition of the Commission in 1998, and with the reduced scale of the conflict and extent of OHAL rule (rescinded in 2002), the new full-time Court decided against fact-finding in successive Turkish cases. The Court's reasoning, referring to problems with the passage of time and lack of documentary evidence (Matyar 2002: para 7), is unconvincing given the previous experience of fact-finding and suggests a policy decision against fact-finding. The following section will demonstrate the impact of the changing role of the ECHR in Turkey and critically assess the Court's approach to state responsibility, redress and sustainable return.

\section{STATE RESPONSIBILITY AND REDRESS}

As a treaty guaranteeing civil and political human rights the ECHR is not well-suited to capturing fully the legal consequences of forced displacement. The ECHR cannot guarantee substantive humanitarian law protections as per the UN Guiding Principles or the Kampala Convention. Nor can it respond to the effects of displacement on the social, economic and cultural rights of individuals and groups. In their translation of the factual findings through a limited range of rights the ECHR 
bodies nonetheless created a significant precedent in international human rights law. The village destructions decisions have been relied on by the UN Committee against Torture (Hajrizi Dzemajl et al v. Yugoslavia 2002), the Inter-American Court of Human Rights (Case of the Ituango Massacres v. Colombia 2006) and the African Commission of Human and Peoples' Rights (Centre for Housing Rights and Evictions $v$. The Sudan 2009) in their subsequent development of legal principles regarding forced evictions and displacement. Problems arise, however, with the ECHR bodies' analysis of the effects of the destruction of homes and denial of access or return.

Throughout the merits decisions the ECHR bodies stressed the deliberate and violent nature of destructions by way of finding "serious" breaches for which no justification had been given, or "a particularly grave and unjustified interference" with applicants' rights to private and family life (Article 8) and the peaceful enjoyment of possessions (Article 1 of Protocol No 1). The destructions had "obliged" the applicants and their families to leave their homes and places of residence. Although prepared to accept the gravity of the violations, neither the Commission nor the Court accepted that the acts of destruction constituted forced displacement. In Akdivar the Commission recognized that the destruction of homes "caused them to abandon their village" but was not satisfied "that the applicants were forcibly expelled" (Akdivar 1995: para 213). The Court similarly noted in Orhan that the village "had to be subsequently evacuated" but refused to rule on whether the forced evacuation of the village was itself a violation (Orhan 2002: para 379). One explanation lies with the inability of fact-finding to establish the motivations behind the destructions. Nonetheless, the failure to distinguish between "evacuations" and the observed arbitrary acts of house destruction and denial of redress or return, or to elaborate any substantive positive duties on the State, sits uneasily with the factual findings. Violations of the prohibition of inhuman treatment (Article 3) were important in recognising the effects on the security, welfare, shelter and livelihood of applicants (e.g. Selçuk and Asker 1996: para 177) and signalling that no justification would permit such treatment (Bilgin 2000: para 102). The denial of domestic redress led to repeated violations of the right to an effective remedy (Article 13). In spite of the repetition, gravity and effects of the violations and lack of redress, claims of a collective punishment, administrative 
practice, and discriminatory policy against Kurdish citizens were abruptly dismissed due to lack of evidence. The IHD/KHRP litigation programme was unable to convince the Commission and Court of the existence of "official tolerance" through the individual cases.

The finding of violations of Articles 3, 8, 13 and P1-1 provided validation of the individual applicants' claims, and compensation by way of pecuniary damages for a range of economic losses. Non-pecuniary damages were also ordered on account of the deliberate nature of the destructions and their "subsequent relocation". The ECHR bodies stressed in relation to Article 13 that claims regarding alleged forced evacuations of villages required "positive state action", either by way of investigations, the provision of alternative housing or of financial assistance (Akdivar 1995: para 240). In the oversight of compliance with the judgments, however, the specific needs of the applicants, and IDPs in Turkey generally, were lost as the Committee of Ministers took the somewhat unusual decision to collectivise the Turkish conflict cases (e.g. Committee of Ministers 2008b). The issue of village destructions was subsumed within a general procedure which "reduced the questions of legal reform, acknowledgement of wrongdoing, and accountability to technical and bureaucratic improvements" (Çali 2010: 313). The concern to address the structural problems with respect to security force accountability was a welcome approach, but came at the cost of passing over the need to deal with past violations and to ensure a sustainable returns process.

The decision to bring an end to fact-finding, and the resulting inability of applicants to substantiate claims of village destructions, prompted a step-change in the Court's review. In the leading 'village returns' case of Doğan (2004) the Court shifted its focus on the need to facilitate the return of the applicants to their villages rather than examine the cause of their displacement almost ten years previously. The Court's assessment was also unusual in that examined the situation of IDPs generally as regards return. In any event, it found that efforts to assist IDPs, through the 'Return to Village and Rehabilitation Project', had "not been converted into practical steps to facilitate the return of the applicants to their villages", citing in particular the fact the applicants' former village remained in ruins (para 154). Additional failures to 
provide alternative housing, employment, or sufficient funds to enable "an adequate standard of living or a sustainable return process", disclosed a disproportionate burden on the applicants in breach of their peaceful enjoyment of possessions (para 154). The subsequent acceptance of a large-scale compensation scheme as an effective remedy for IDPs (Içyer 2006) brings us back to the lesson from Donnelly: the provision, or reasonable prospects, of compensation will often be enough to satisfy the Court on domestic remedies.

The Içyer decision turned on the applicants' failure to refute the government's evidence of 440 successful domestic claims for denial of access to property and loss of income. Compensation was deemed available in theory and practice to IDPs, with practical benefits to the Court by clearing around 1,500 pending village returns applications from its docket (including 57 published decisions regarding 590 applications submitted by 1,599 applicants). The reduction of the issue of sustainable return to compensation, unaccompanied by measures on housing, adequate standards of living, or satisfaction, can provide only limited gains. The absence of responsibility is secured through the compensation scheme's discourse, whereby displacement is reconstituted as a mere by-product of the "fight against terrorism" (Sert, 2016: 6, 8). Cali argues, for instance, that the compensation scheme enables "a continuation of the government's security narrative" by failing to acknowledge responsibility (Çali 2010: 332). Others posit the compensation scheme as a form of "selective regulation of the consequences of internal displacement" rather than an effort to address the underlying causes (Ayata and Yükseker 2005: 32) and question the fairness of various aspects of the Compensation Law system (Kurban et al 2006: 33-40; Sert, 2016: 8-9). The EU also expressed concerns about its effectiveness prior to Íçyer (EU Commission 2005: 38-39).

The Committee of Ministers closed its supervision of the government's compliance with Doğan in June 2008 (Committee of Ministers 2008a) with the effect that there is no running oversight of implementation at Strasbourg. The Court subsequently rejected further challenges to the Compensation Law in the Akbayrr-group of cases (2011); four published decisions relating to 1,017 applications. The general dissatisfaction with the Içyer decision is well-founded on a holistic understanding of 
displacement and sustainable return. Indeed, the EU Commission continues to question the lack of a comprehensive strategy to assist IDPs in Turkey (EU Commission 2015: 25-26). Such criticism, however, betrays unrealistic expectations of what the ECHR system can, or is willing to, offer on remedies for this large-scale, protracted displacement. The post-1998 Court has turned away from the earlier proactive approach and sought to re-emphasise the subsidiary status of the ECHR. The Court's pragmatism is evident throughout the Íçyer and Akbayir-group decisions, with progress towards ensuring access to domestic financial settlements taking sole priority. Displacement in Turkey cannot be fully resolved by compensatory redress of property rights violations, nor have the ECHR judgments acted as a disincentive to further acts of forced displacement (Human Rights Watch 2016). Sustainable return, for those who desire to return, is contingent upon the conclusion of a broader political process and rights-based peace agreement that addresses the legacy of conflict and security policies in the South-east.

\section{CONCLUSION}

The record of the ECHR in Turkey illustrates the complexities involved in litigating displacement, but also the capacity of strategic litigation to deliver various outcomes. The ECHR proceedings had distinct impacts for victims, NGOs and civil society, particularly at the admissibility and fact-finding stages. From the IHD/KHRP litigation programme we can clearly observe the importance of local and international co-ordination to the pursuit of an ambitious legal strategy. The advance selection of priority issues and combined legal knowledge were instrumental in securing a protective form of access to justice at Strasbourg. The IHD/KHRP successes also served as encouragement to lawyers in Turkey, who continue to engage the ECHR system across a broad range of human rights issues. Regional tribunals are likely to struggle to get to the underlying issues and causes of conflict and of displacement. Furthermore, the Turkish experience attests to the real possibility that genuine, appropriate and effective transitional justice measures are side-lined by limited remedial schemes. NGOs, lawyers and activists must also work strategically to ensure the causes and legal consequences of displacement are not 
lost within broader political and technical processes of reform or conflictmanagement or resolution.

Regional human rights tribunals can, and will, modify their normal mode of operation where violations occur within the context of a general restriction on rights. In cases of conflict-induced displacement the possibility of direct or special access to regional tribunals presents an opportunity to expose and identify, at a procedural stage, patterns of immunity and denial. The exhaustion of domestic remedies rulings sent a clear message that an absence of local protection and redress would not stand untested as a result of strict application of procedural rules. By assuming a distinctive form of oversight of the situation in South-east Turkey the ECHR bodies gave substantive meaning to the requirement of effective remedies and contributed a record of events in the OHAL region. The experience of ECHR factfinding in Turkey also speaks, however, to the structural limitations of ECHR system. The right to individual petition and the limited capacity of ECHR fact-finding both inhibited the ability of the ECHR bodies to examine fully the scope and causes of displacement in Turkey. The role of fact-finding and truth processes, and their social purchase, in the context of displacement is a topic deserving closer attention. Equally important is the need to elaborate context-specific guidelines on human rights, transitional justice and sustainable returns processes. In this way we can hope to inform and improve the legal regulation of displacement.

\footnotetext{
NOTES

i The Commission was abolished and a full-time Court was created by Protocol No. 11 to the ECHR (1994). ii All figures given in the text are based on the database. The author is aware of a series of unpublished inadmissibility decisions; email communication with the Registry of the Court, 26 May 2009 \& 9 September 2015.

iii The 'village guards' system requires villagers to work alongside security forces in military operations and to defend villages against the PKK.

iv A term used by Mehmet Nur Terzi, speaking of his plan regarding the filing of detention complaints under the ECHR (Human Rights Watch 1996: 31).
}

\section{CASES}

Ahmet Özkan and Others v. Turkey (21689/93) 6 April 2004

Akbayır and Others v. Turkey (Ad) (30415/08) 28 June 2011, Press Release 102 (2011),

8 July 2011 
Akdivar and Others v. Turkey (Ad) (21893/93) 19 October 1994

Akdivar and Others v. Turkey (Report) (21893/93) 26 October 1995

Akdivar and Others v. Turkey [GC] (21893/93) 16 September 1996

Altun v. Turkey (24561/94) 1 June 2004

Ayder and Others v. Turkey (Report) (23656/94) 21 October 1999

Ayder and Others v. Turkey (23656/94) 8 January 2004

Bilgin v. Turkey (23819/94) 16 November 2000

Case of the Ituango Massacres v. Colombia, 1 July 2006, Series C No. 148 (Inter-

American Court of Human Rights)

Case of the Mapiripán Massacre v. Colombia, 15 September 2005, Series C No. 134 (InterAmerican Court of Human Rights)

Centre for Housing Rights and Evictions (COHRE) v. The Sudan, Comm. 296/05, 13-27

May 2009 (African Commission on Human and Peoples' Rights)

Denmark, Norway, Sweden and the Netherlands v. Greece (Report) 3321-23/67, 3344/67) 5 November 1969

Doğan and Others v. Turkey (8803-11/02; 8813/02; 8815-19/02) 29 June 2004

Donnelly and Others v. United Kingdom (Ad) (5577-83/72) 5 April 1973

Donnelly and Others v. United Kingdom (Ad) (5577-83/72) 15 December 1975

Dulaşv. Turkey (Ad) (25801/94) 23 May 1996

Elek and Others v. Turkey (Ad) (26679/95) 22 March 2001

Gündem v. Turkey (Report) (22275/93) 3 September 1996

Hajrizi Dzemajl et al v. Yugoslavia, Comm. 161/2000, CAT/C/29/D/161/2000, 2

December 2002 (UN Committee against Torture)

Hasan Illhan v. Turkey (22494/93) 9 November 2004

İçer v. Turkey (Ad) (18888/02) 12 January 2006

Ipek v. Turkey (Ad) (25760/94) 14 May 2002

Ipek v. Turkey (25760/94) 17 February 2004

Ireland v. United Kingdom (Report) (5310/71) 21 January 1976

Matyar v. Turkey (23423/94) 21 February 2002

Menteș and Others v. Turkey (Report) (23186/94) 7 March 1996

Menteş and Others v. Turkey (23186/94) 28 November 1997

Orhan v. Turkey (25656/94) 18 June 2002

Selçuk and Asker v. Turkey (Report) (23185-5/94) 28 November 1996

Selçuk and Asker v. Turkey (23184-5/94) 24 April 1998

Yilmaz and Others v. Turkey (Report) (23179-82/94) 9 September 1997

Yöyler v. Turkey (26973/95) 24 July 2003

\section{REFERENCES}

Ayata, B. and Yükseker, D. 2005 "A Belated Awakening: National and International Responses to the Internal Displacement of Kurds in Turkey", New Perspectives on Turkey, 32: 5-42.

Çali, B. 2010 "The Logics of Supranational Human Rights Litigation, Official Acknowledgement and Human Rights Reform: The Southeast Turkey Cases before the European Court of Human Rights, 1996-2006", Law and Social Inquiry, 35(2): 311-337. 
Cançado Trindade, A.A. 1983 The Application of the Rule of Exhaustion of Local Remedies in International Law: Its Rationale in the International Protection of Individual Rights, Cambridge University Press.

Cavallaro, J.L. and Brewer, S.J. 2008 "Re-evaluating Regional Human Rights Litigation in the Twenty-First Century: The Case of the Inter-American Court", American Journal of International Law, 102(4): 768-827.

Çelik, A.B. 2012 "State, Non-Governmental and International Organizations in the Possible Peace Process in Turkey's Conflict-Induced Displacement", Journal of Refugee Studies, 26(1): 1-25.

Cohen, R. 1998 "Recent Trends in Protection and Assistance for Internally Displaced People”, in: Hampton, J. (ed.) 1998 Internally Displaced People: A Global Survey, Earthscan Publications, 3-9.

Cohen, R. 2004 "The Guiding Principles on Internal Displacement: An Innovation in International Standard Setting", Global Governance, 10(4): 459-480.

Cohen, R. and Deng, F.M. 1998 Masses in Flight: The Global Crisis of Internal Displacement, Brookings Institution Press.

Committee of Ministers of the Council of Europe

2008 "Execution of the Judgment of the European Court of Human Rights in Doğan and Others v. Turkey", Resolution DH(2008)60, 25 June 2008.

2008 "Actions of the Security Forces in Turkey: Progress Achieved and Outstanding Issues", Interim Resolution CM/ResDH(2008)69, 18 September 2008.

Dickson, B. 2010 The European Convention on Human Rights and the Conflict in Northern Ireland, Oxford University Press.

European Commission (EU)

2015 "Commission Staff Working Document: Turkey 2015 Report”.

2005 "Regular Report on Turkey's Progress Towards Accession".

Giustiniani, F.Z. 2011 "New Hopes and Challenges for the Protection of IDPs in Africa: The Kampala Convention for the Protection and Assistance of Internally Displaced Persons in Africa", Denver Journal of International Law and Policy, 39(2): 347-370.

Gündüz, A. 2001 “Human Rights and Turkey's Future in Europe”, Orbis, 45(1): 15-30. 
Helfer, L.R. 2008 "Redesigning the European Court of Human Rights: Embeddedness as a Deep Structural Principle of the European Human Rights Regime”, European Journal of International Law, 19(1): 125-159.

Helfer, L.R. and Slaughter, A.M. 1997-1998 “Toward a Theory of Effective Supranational Adjudication", Yale Law Journal, 107(2): 273-391.

Human Rights Watch

2016 "Turkey: State Blocks Probes of Southeast Killings", <https:/www.hrw.org/news/2016/07/11/turkey-state-blocks-probes-southeast-

killings>

1996 "Turkey: Violations of the Right of Petition to the European Commission on Human Rights", Vol. 8 No. 4.

Kälin, W. 2008 "The Future of the Guiding Principles", Forced Migration Review: 10 Years of the Guiding Principles on Internally Displaced Persons 38-39.

Kurban, D., et al. 2006 Overcoming a Legacy of Mistrust: Towards Reconciliation Between the State and the Displaced, Norwegian Refugee Council / Internal Displacement Monitoring Centre / Turkish Economic and Social Studies Foundation.

Leach, P., et al. 2009 "International Human Rights and Fact-Finding: An Analysis of the Fact-Finding Missions Conducted by the European Commission and Court of Human Rights", Human Rights and Social Justice Research Institute, London Metropolitan University.

Lee, L.T. 2001 "The London Declaration of International Law Principles on Internally Displaced Persons", American Journal of International Law, 95: 454-458.

McEvoy, K. 2011 “What Did the Lawyers Do During the 'War'? Neutrality, Conflict and the Culture of Quietism", Modern Law Review, 74(3): 350-384.

Reidy, A., et al. 1997 "Gross Violations of Human Rights: Invoking the European Convention on Human Rights in the Case of Turkey", Netherlands Quarterly of Human Rights, 15(2): 161-173.

Sert, D. 2016 "Turkey's Position on IDP Properties: Lessons (Not) Learned", International Migration (Special Issue: Peace Processes and Durable Returns) (forthcoming).

Stavropoulou, M. 1994 "The Right Not to Be Displaced", American University International Law Review, 9(3): 689-749. 
Steiner, H.J. and Alston, P. 2000 International Human Rights in Context: Law, Politics, Morals, Oxford University Press.

UN Commission on Human Rights

1998 "Report of the Representative of the Secretary-General, Mr Francis Deng, submitted pursuant to Resolution 1997/39", E/CN.4/1998/53/Add.2.

1992 “Internally Displaced Persons”, E/CN.4/RES/1992/7.

Vivanco, J.M. and Bhansali, L.L. 1998 "Procedural Shortcomings in the Defence of Human Rights: An Equality of Arms", in: Harris, D.J. and Livingstone, S. (eds.) The InterAmerican System of Human Rights, Clarendon Press, 421-440.

Yildiz, K. and Brigham, C. 2006 Human Rights Defenders in Turkey, Kurdish Human Rights Project / Bar Human Rights Committee of England and Wales.

Zwaak, L. 1997 "The European Court of Human Rights has the Turkish Security Forces Held Responsible for Violations of Human Rights: The Case of Akdivar and Others", Leiden Journal of International Law, 10(1): 99-110. 